\section{PROFESIONALNE KOMPETENCIJE SOCIJALNIH RADNIKA: TEMELJ IDENTITETA JEDNE POMAŽUĆE PROFESIJE}

Pregledni članak

Primljeno: srpanj, 2019.

Prihvaćeno: veljača, 2020. UDK 364.62:174

DOI 10.3935/ljsr.v27i1.319

Marko Buljevac ${ }^{1}$ orcid.org/0000-0001-7128-7860

Ana Opačić2

orcid.org/0000-0002-3486-0696

Sveučlišste u Zagrebu

Pravni fakultet

Studijski centar socijalnog rada

Martina Podobnik ${ }^{3}$ orcid.org/0000-0001-7293-5794

Hrvatska komora socijalnih radnika

Ključne riječi:

profesionalne kompetencije, profesionalni identitet, cjeloživotno obrazovanje, socijalni rad.
1 Doc.dr.sc. Marko Buljevac, socijalni radnik, e-mail: marko.buljevac@pravo.hr

2 Doc.dr.sc. Ana Opačić, socijalna radnica, e-mail: ana.opačić@pravo.hr

3 Martina Podobnik, socijalna radnica, e-mail: mpodobnik91@gmail.com 
specifični okviri kompetencija u pojedinim područjima socijalnog rada, no zbog velikog stupnja slaganja s generičkim okvirom donosi se zaključak kako se generički okvir može djelotvorno nadograditi za primjenu u specifičnom području socijalnog rada. Nacionalni okvir profesionalnih kompetencija socijalnih radnika razvijen u suradnji akademske zajednice, praktičara i strukovnih organizacija može pridonijeti profesionalnom identitetu socijalnih radnika, unaprjeđenju profesionalnog i karijernog razvoja, omogućava usklađivanje prakse i obrazovanja, otvara nova istraživačka područja i može biti podloga za razvoj specifičnih kompetencija u područjima socijalnog rada.

\section{UVOD}

Uvid u profesionalne kompetencije predstavlja temelj za identificiranje uloge određene profesije u društvu. Profesionalne kompetencije definiraju se u skladu sa zadacima koje neka profesija mora obavljati što doprinosi izgradnji profesionalnog identiteta stručnjaka koji joj pripadaju. Poznavanje sadržaja profesionalnih kompetencija socijalnih radnika omogućava uvid u to što socijalni rad jest i kako može odgovoriti na socijalne probleme. Pristup usmjeren na kompetencije razvija se 80 -ih i 90-ih godina 20. stoljeća, iako se prvi treninzi utemeljeni na kompetencijama pojavljuju u području industrijske psihologije još početkom 20. stoljeća (Anderson-Levitt, Bonnéry i Fichtner, 2017.). Tijekom 70-ih godina 20. stoljeća pojavljuje se snažan pokret u pedagoškom obrazovanju s naglaskom na ponašajni aspekt kompetencija, dok se 80-ih godina 20. stoljeća proširuje shvaćanje kompetencija (Anderson-Levitt, Bonnéry i Fichtner, 2017.). Kompetencije su temelj razvoja obrazovnih kurikuluma i način da se obrazovni programi približe zahtjevima na tržištu rada (UNESCO, 2019.). U posljednjih 25 godina pronalazimo sve više obrazovnih programa za socijalni rad utemeljenih na kompetencijama (Drisko, 2014.).

Cilj ovog rada je produbiti razumijevanje profesionalnih kompetencija u socijalnom radu kroz prikaz dimenzija i područja profesionalnih kompetencija na generičkoj razini, pristupa u mjerenju kompetencija te predstavljanje okvira kompetencija u pojedinim područjima socijalnog rada. Svrha rada je dati poticaj da se u hrvatskom kontekstu izgradi okvir profesionalnih kompetencija čime bi se unaprijedilo profesionalno djelovanje socijalnih radnika i obrazovni programi namijenjeni socijalnim radnicima.

\section{Dimenzije i područja profesionalnih kompetencija u socijalnom radu}

Kompetentno djelovanje socijalnih radnika očituje se u djelotvornom obavljanju radnih zadataka koristeći stručna znanja i vještine. Međutim, pretjerano tehnokratsko 
inzistiranje na djelotvornosti ima rizike za socijalni rad. Ukoliko se socijalni rad kao kompleksna profesija, koja je duboko isprepletena s društvenim kontekstom, svede na niz mjerljivih profesionalnih zadataka, to može dovesti do njene deprofesionalizacije (Dominelli, 1996.). Dominelli (1996.) rizik od deprofesionalizacije povezuje s visokim stupnjem specijalizacije po modelu tejlorizma gdje će se kompleksni dinamični procesi u socijalnom radu koji čine jednu integralnu razinu razdijeliti na set visoko definiranih zadataka, a posljedično ono što čini kompleksan posao jednog praktičara, moći podijeliti na niz stručnjaka koji ne moraju nužno biti visokokvalificirani za pojedine zadatke. Kako bi se to izbjeglo, suvremeni pogled na profesionalne kompetencije temelji se na trokutu znanja - vještina - vrijednosti (Drisko, 2014.). Na taj se način šalje poruka da djelotvornost nije jedino mjerilo kompetentnosti, već je to i osobni odnos stručnjaka prema profesiji, pa kompetencije sudjeluju u izgradnji profesionalnog identiteta.

Drugim riječima, nije važno samo što je stručnjak sposoban učiniti, već i koje svoje osobne dimenzije treba osnaživati. Kompetentan stručnjak istovremeno razvija kognitivnu, afektivnu i psihomotornu razinu (Bracy, 2018.). Kognitivna dimenzija uključuje integrirano znanje te sposobnost procesiranja informacija na način koji vodi razumijevanju, primjeni, analizi, evaluaciji i osmišljavanju stručnih postupaka. Afektivna razina kompetentnosti povezuje se s procesom profesionalne socijalizacije i uključuje odnos prema osobnim, društvenim, političkim i profesionalnim vrijednostima. Od stručnjaka se očekuje da može razumjeti profesionalne vrijednosti, kritički ih propitati, razriješiti potencijalne konflikte vrijednosnih okvira i internalizirati ih. Psihomotorna razina odražava usvojenost vještina, odnosno izvođenje specifičnih zadataka (Bracy, 2018.).

Američko udruženje Vijeće za obrazovanje u socijalnom radu (Council on Social Work Education, 2015.;6) kao organizacija koja je vjerojatno najpoznatija u području sistematizacije profesionalnih kompetencija, profesionalne kompetencije socijalnih radnika određuje na sljedeći način: "Kompetencije u socijalnom radu su sposobnost integracije i primjene znanja socijalnog rada, vrijednosti i vještina kako bi se praksa obavljala na svrhovit, usmjeren i profesionalan način s ciljem promocije dobrobiti ljudi i zajednica. Prepoznaje se holističko viđenje kompetencija, odnosno kompetencije se iskazuju s obzirom na usvojena znanja, vrijednosti i vještine, te kognitivne i afektivne procese koji uključuju kritičko mišljenje, emocionalne reakcije, procjenu s obzirom na specifičnost situacija uočenih u praksi. Profesionalne kompetencije su multidimenzionalne i sastavljene od međusobno povezanih kompetencija. Kompetencije socijalnog radnika se sagledavaju kao razvojne, dinamične, promjenjive u vremenu i u vezi sa cjeloživotnim učenjem". Kompetencije kao ukupnost znanja, vještina i vrijednosti mogu biti određene na generičkoj razini ili se mogu specifično definirati u pojedinim područjima socijalnog rada. Prema modelu profesionalnih kompetencija autorice Bogo (2010.), generičke kompetencije mogu se podijeliti u kompetencije prve razine 
ili metakompetencije te kompetencije druge razine ili procesne kompetencije. Prema Bogo (2010.), metakompetencije sastoje se od:

a) kognitivnih ili konceptualnih kompetencija usmjerenih na rješavanje problema, kritičko mišljenje, analitički pristup i kreativnost

b) interpersonalne kompetencije koje su usmjerene na stvaranje povezujućih odnosa, pružanje podrške i suradnju

c) osobne ili profesionalne koje se tiču odnosa stručnjaka prema profesiji te

d) vrijednosti i etiku.

Procesne kompetencije su kompetencije druge razine gdje je u središtu proces rada s korisnikom, za što su važne dimenzije procjena, intervencija, komunikacija i prezentacija profesionalnog rada (Bogo, 2010.). U radu će se prikazati područja kompetencija držeći se podjele na metakompetencije i procesne kompetencije.

Broj i sadržaj područja profesionalnih kompetencija različito se određuje u dokumentima nacionalnih strukovnih organizacija (sve redom iz anglosaksonskog područja) (Council on Social Work Education, 2012.; Australian Association of Social Workers, 2013.; British Association of Social Workers, 2013.; Canadian Association for Social Work Education, 2014.) i znanstvenim istraživanjima (Holden, Anastas i Metrey, 2002.; Williams, King i Koob, 2002.; King, 2003.; Rishel i Majewski, 2009.; Cournoyer, 2011.; Pedrazza i sur., 2013.; Holden i sur., 2017.; Tompsett i sur., 2017.; Wang i Chui, 2017.). Na temelju analize navedenih izvora, predlaže se osam područja profesionalnih kompetencija čije objašnjenje upravo slijedi, od čega je jedno područje procesnih kompetencija te sedam područja metakompetencija.

Procesne kompetencije u socijalnom radu odnose se na izravan rad s korisnicima, od uspostavljanja odnosa, procjene, planiranja intervencija, provedbe do evaluacije i završavanja rada. Tijekom cijelog procesa važne su komunikacijske vještine, a za socijalne radnike posebno je izazovno raditi s nedobrovoljnim korisnicima i prilagoditi komunikaciju različitim korisnicima. U fazi procjene ističu se kompetencije prikupljanja i integracije podataka iz različitih izvora te istovremeno snalaženje u terenskim posjetima, direktnom razgovoru i ispunjavanju administrativnih zahtjeva. U fazi ugovaranja i planiranja socijalni radnici trebaju ostvariti partnerski odnos $\mathrm{s}$ korisnikom i članovima iz njegove okoline u izradi individualnog plana. Ugovaranje se temelji na zajedničkom postavljanju ciljeva uz definiranje mjerljivih ishoda i jasnog obrazloženja kako su ciljevi povezani s planiranim intervencijama u realnom vremenskom okviru. Važan aspekt je analiza potencijalnih rizika i osmišljavanje aktivnosti koje smanjuju štetne posljedice rizika. Prilikom provedbe intervencija, socijalni radnici trebaju pokazati znanje i vještine primjene određenih metoda i tehnika unutar adekvatnog zakonskog okvira. 
Izazov za socijalne radnike predstavljaju otpori korisnika, agresivna i manipulativna ponašanja, a često je zadatak socijalnog radnika koordinirati rad drugih stručnjaka unutar i izvan institucije. Tijekom provedbe intervencija, socijalni radnici trebaju prepoznati kada je vrijeme da promijene način djelovanja ako postojeći ne daje rezultate, kao i prethodno biti spremni na mogući rezervni plan djelovanja. Proces rada s korisnicima trebao bi završiti finalnom evaluacijom, iako je evaluaciju važno i kontinuirano provoditi. Korisnicima će kompetentan socijalni radnik jasno ukazati kako mogu ocijeniti njihov rad, kao i rad ustanove, odnosno kako mogu izraziti svoje nezadovoljstvo. Proces rada s korisnicima završava zatvaranjem procesa, proradom emocija glede završetka i odlukom treba li i nakon završetka procesa pomaganja napraviti praćenje korisnika. Tijekom procesa rada s korisnicima, socijalni radnici trebaju iskazati vještine pisane formalne komunikacije kako bi lakše strukturirali i pratili svoj stručni rad.

Sedam područja metakompetencija su: profesionalno ponašanje i profesionalni identitet; profesionalna etika; multikulturalnost i inkluzivna praksa; kritički strukturalni pristup; integracija teorije u praksi i kritičko mišljenje; međusektorska suradnja i makropristup; vodstvo i funkcioniranje u organizaciji.

Profesionalno ponašanje i profesionalni identitet područje je kompetencija koje se odnosi na osviještenost profesionalnog identiteta i razumijevanje uloge socijalnog rada u različitim radnim okruženjima. Socijalni radnik svojim ponašanjem i načinom prezentacije promovira profesiju te kontinuirano radi na vlastitom profesionalnom razvoju. Profesionalnost znači biti kritičan prema sebi kao stručnjaku kako bi se osvijestile osobne pristranosti, primjereno postavile profesionalne granice, uočio sukob osobnog i profesionalnog te utvrdile potrebe za dodatnim znanjima i vještinama. U kontekstu socijalnog rada važno je da stručnjak osvijesti poziciju moći, odnosno da prepozna i korigira situacije kada moć prema korisnicima koristi na neprimjeren način.

Profesionalna etika uključuje znanje o profesionalnoj etici i primjenu etičkih načela u praksi. Socijalni radnici trebaju znati važeći etički kodeks, zakonodavni okvir koji regulira profesiju i sadržaj profesionalnih vrijednosti. Također trebaju imati vještine da prepoznaju etička pitanja i dileme, da aktiviraju mehanizme njihova razrješenja te da mogu preispitati osobne u odnosu na profesionalne vrijednosti. Posebno se naglasak stavlja na implementaciju nekoliko etičkih načela u praksi: načelo sudjelovanja korisnika u donošenju odluka, poštovanje privatnosti korisnika, samoodređenje i poštovanje dostojanstva korisnika. Načelo sudjelovanja u donošenju odluka naglašava partnerski pristup s korisnicima te kompetenciju jasnog obrazloženja kada je mogućnost suradnje ograničena. Pravo na privatnost odnosi se jednako na zaštitu privatnosti unutar i izvan obitelji, uz jasnoću kada je ono nadjačano drugim pravnim i profesionalnim zahtjevima. Pravo na samoodređenje i poštovanje dostojanstva 
korisnika podrazumijevaju autonomiju korisnika u donošenju životnih izbora, otvorenost za individualne različitosti te potrebu da se o korisniku govori bez korištenja stigmatizirajuće komunikacije.

Načelo multikulturalnosti i inkluzivne prakse ističe se posljednjih godina u vremenima intenzivnih migracija i izgradnje multikulturnih društava. Kulturalne kompetencije implicitno uključuju svijest vlastite kulture i iskrenu želju da se upoznaju različite kulture, što dalje rezultira inovativnom i kreativnom praksom koja se nastoji približiti različitim skupinama korisnika. S obzirom da različitost često dolazi uz iskustvo diskriminacije, sastavni element ovog područja kompetencija je antiopresivna praksa.

Kritički strukturalni pristup i zagovaranje ljudskih prava te socijalne, ekonomske i ekološke pravde stavlja pred socijalne radnike očekivanja da znaju izvore društvenih nejednakosti, da se aktivno uključe u zagovaračke inicijative i da prepoznaju kada i sama njihova praksa i zakoni postaju nepravedni. Od kompetentnih socijalnih radnika očekuje se da budu u toku s političkim, ekonomskim, tehnološkim i ekološkim procesima kako bi mogli pravovremeno uočiti narušavanje položaja marginaliziranih društvenih skupina. Korak dalje čini iniciranje i sudjelovanje u socijalnoj akciji i zagovaračkim aktivnostima, a posebno je važan kritički odnos prema praksi i zakonodavnom okviru. Naime, iskustva pokazuju da zakonski okvir, tumačenje zakona, pisane i nepisane prakse institucije, kao i primjena mjera socijalnog rada (posebice onih represivnog karaktera) u nekim okolnostima može dodatno pogoršati položaj korisnika. Od socijalnih radnika očekuje se da aktivno doprinose pravednijoj praksi, pravednijem sustavu socijalne skrbi te uopće pravednijem društvu.

Integracija teorije u praksi i kritičko mišljenje kao područje kompetencija ukazuje da nije važno samo što socijalni radnici znaju, već i na koji način donose prosudbe u svom radu i kako integriraju raznovrsne spoznaje. U korpusu stručnog znanja važnog za socijalni rad nalaze se teorije koje govore o društvenom razvoju, sistemskom razumijevanju osobe u okruženju, psihičkom i fizičkom razvoju čovjeka te teorijsko znanje iz metodskih područja (rad s pojedincem, obitelji, grupom i u zajednici). Uz teorijsko znanje, socijalni radnici stječu znanje iz drugih izvora, tj. od korisnika, iz praktičnog iskustva i iz istraživanja. Kompetencije se očituju u uspješnosti integriranja različitih izvora spoznaja, iskazivanju kreativnosti u rješavanju problema korisnika, vještinama argumentacije profesionalnih odluka i u sposobnosti da se u svjetlu novih informacija promijeni stajalište.

Međusektorska suradnja i makropristup pozicioniraju socijalni rad u šire društveno okruženje. Socijalni rad je profesija koja povezuje različite dionike, aktivira lokalne resurse i podiže svijest zajednice o socijalnim pitanjima neovisno o radnom mjestu na kojem je stručnjak zaposlen. Socijalni radnici imaju ulogu razvijati socijalne programe, nove usluge i volonterske programe, poticati koordinaciju drugih službi 
i stručnjaka, aktivirati se u unaprjeđenju lokalne, regionalne i nacionalne politike, procjenjivati efekte javnih politika te održavati kontakt sa stanovništvom kako bi se radilo na prevenciji i senzibilizaciji za socijalne probleme.

Vodstvo i funkcioniranje u organizaciji je područje kompetencija koje je usmjereno na osnaživanje same profesije. Očekuje se da dio radnog angažmana, pa i radnog vremena, bude posvećen organizacijskom razvoju. Literatura prepoznaje da se ovo područje kompetencija neće dogoditi "samo po sebi", te da za kvalitetno organizacijsko funkcioniranje treba izdvojiti vrijeme i druge resurse, uz kontinuirano educiranje u tom području. Djelotvorno funkcioniranje u organizaciji znači da se njeguje kolegijalnost, ali i razumiju pisana i nepisana pravila njena ustroja. Nadalje, to znači proaktivno zagovaranje organizacijskih promjena, bez obzira na ulogu socijalnog radnika u hijerarhiji, a kako bi ukupno kvaliteta rada s korisnicima bila bolja. Za socijalne radnike je posebno važno biti kompetentan u timskom radu uz poznavanje timske dinamike i kvalitetno rješavanje sukoba u timu. Konačno, socijalni radnici odgovorni su za profesionalnu socijalizaciju novih stručnjaka u procesima mentorstva te mogu biti model za primjenu određenih metoda i tehnika po kojima su prepoznati u profesionalnoj zajednici. Socijalni radnici nositelji su razvoja vlastite profesije, trebaju razumjeti društvene procese koji na nju djeluju te doprinijeti sudjelovanjem u strukovnim organizacijama i komorama.

\section{ZNAČAJ PROFESIONALNIH KOMPETENCIJA ZA PROFESIONALNI IDENTITET, PRAKSU, KARIJERNI RAZVOJ I OBRAZOVANJE}

Izgradnja okvira profesionalnih kompetencija ima višestruku dobit za profesionalni identitet, rad u praksi, karijerni razvoj i obrazovni sustav u socijalnom radu. Posebice je osnažujuće za profesiju što se izgradnja okvira kompetencija treba odvijati u partnerstvu akademske zajednice i strukovnih organizacija. Navedeno je već samo po sebi značajan proces. Profesionalne kompetencije u dvostrukom su odnosu s profesionalnim identitetom. Profesionalni identitet istovremeno je dio kompetencija i njihov rezultat. Od kompetentnih socijalnih radnika očekuje se da integriraju profesionalne vrijednosti, da u različitim kontekstima razumiju ulogu socijalnog rada, da ulažu u razvoj profesije sudjelovanjem u strukovnim udruženjima i da pomognu u profesionalnoj socijalizaciji mlađih kolega. Na ove načine socijalni radnici pokazuju profesionalni identitet. Međutim, ukupnost ovladavanja profesionalnim kompetencijama i doživljaj da stručnjak sudjeluje u realizaciji ciljeva i misije profesije jača njihov identitet. 
Webb (2016.) je istaknuo nekoliko važnih spoznaja za razumijevanje profesionalnog identiteta. Identitet nije stabilna karakteristika, već se radi o kontinuiranom procesu odgovaranja na zahtjeve u radnom okruženju; ključan čimbenik formiranja je profesionalna socijalizacija, a u socijalnom radu izgradnja identiteta odvija se u kontekstu nejednakih pozicija moći te socijalni radnici internaliziraju istovremeno "poslušnost" i otpor javnom sustavu. Promišljanje identiteta ne može se odvijati odvojeno od organizacijske strukture, a za identitet socijalnog rada od ključne je važnosti demarkacija ili strukturalno definiranje razlikovnih obilježja od drugih bliskih profesija.

Kompetencije su jasna poveznica obrazovanja i prakse izgrađujući most između promjenjivih društvenih okolnosti i ulaska u profesiju novih stručnjaka. Okvir kompetencija omogućuje stvaranje razlikovanja od drugih profesija te može biti platforma za karijerni razvoj socijalnih radnika. U nekim područjima kompetencija eksplicitno se potiče socijalne radnike da uoče potrebu za cjeloživotnim obrazovanjem, da nađu mehanizme vlastitog razvoja i da postanu prepoznatljivi ili specijalizirani u nekom području prakse. Poticajan okvir profesionalnih kompetencija za karijerni razvoj nudi Britansko udruženje socijalnih radnika (British Association of Social Workers, 2013.) prema kojem godine iskustva nisu jamstvo profesionalnog razvoja niti se očekuje da svi socijalni radnici jednako ovladaju svim područjima kompetencija. Upravo navedeno udruženje razvilo je pet prilagođenih okvira profesionalnih kompetencija za razinu socijalnog radnika pripravnika, socijalnog radnika, iskusnog socijalnog radnika, naprednog socijalnog radnika i socijalnog radnika za strateški razvoj. Za ilustraciju može se prikazati kompetencija u području vrijednosti i etike.

Pripravnik socijalni radnik trebat će razumjeti i primijeniti etičke principe i zakonski okvir tijekom donošenja odluka; socijalni radnik će trebati dodatno iskazati sigurnost u primjeni etičkog zaključivanja uz osvještavanje drugih o tome kako oni koriste etički i zakonski okvir; iskusni socijalni radnik neće samo osvijestiti, nego i osnažiti druge da na prikladan način koriste etički i zakonski okvir; napredni socijalni radnik će modelirati i promovirati etičko donošenje odluka i u tome biti uzor, dok će socijalni radnik na najvišem stupnju osigurati sistemske mehanizme koji podržavaju etičko donošenje odluka i implementaciju zakonskog okvira. Prilagođeni okviri su snažan alat samoevaluacije stručnjaka i nude potencijal za ciljano karijerno praćenje i nagrađivanje u profesionalnom razvoju.

Pristup usmjeren na kompetencije omogućuje lakše usklađivanje formalnog obrazovanja s praksom i zato je važno da se nacionalni okvir kompetencija definira u suradnji akademske i profesionalne zajednice. Time okvir kompetencija postaje temelj planiranja kurikuluma i terenske prakse s detaljno razrađenim indikatorima i ishodima učenja koji jamče doprinos kompetencijama. Vijeće za obrazovanje u socijalnom radu (Council on Social Work Education, 2015.) na temelju okvira od deset kompetencija 
daje suglasnost za akreditaciju preddiplomskih i diplomskih studija socijalnog rada u SAD-u. Dodatno se u suradnji nastavnika i terenskih nastavnika razrađuju zadaci terenske prakse i indikatori evaluacije terenske prakse kako bi se postigla usklađenost ključnih kompetencija s ishodima učenja.

Približavanje obrazovanja zahtjevima profesije u sinergiji je i s pristupom kvalifikacijskog okvira koji promovira Europska unija. Prema preporuci Vijeća Europske unije (2017.), kvalifikacije su formalni rezultat završetka obrazovnog programa koji jamči ostvarenost ishoda učenja. Ishodi učenja opisuju što pojedinac zna i razumije te za što je sposoban, dok su kompetencije dokazana sposobnost upotrebe stečenih sposobnosti. Kvalifikacijski okvir donekle formalizira posjedovanje kompetencija definirajući kvalifikacije koje netko treba posjedovati da bi bio licenciran u reguliranoj profesiji (kakva je socijalni rad), usmjerava razvoj obrazovnih programa i pomaže individualnom profesionalnom razvoju. Okvir kompetencija omogućuje usklađeno vrednovanje obrazovnih programa bez obzira na njihovu različitost u kurikulumu i trajanju. Može se zaključiti kako okvir profesionalnih kompetencija služi kao dogovoreni standard oko toga što znači biti socijalni radnik i kako bi trebala izgledati njegova društvena uloga.

\section{NAČIN MJERENJA I OPERACIONALIZACIJE PROFESIONALNIH KOMPETENCIJA}

Mjerenje profesionalnih kompetencija dijeli se na pristup samoprocjene i vanjsko mjerenje koje je obično moguće kada su sudionici mjerenja istovremeno sudionici edukacije. Većina istraživanja koristi se metodama samoprocjene uz koju se vežu već poznati nedostaci (npr. različite introspektivne sposobnosti pojedinaca, davanje društveno poželjnih odgovora i druge). Istraživači su često usmjereni na procjene samoefikasnosti s mjerenjem u dvije vremenske točke (prije i poslije sudjelovanja u obrazovnom programu). Koncept samoefikasnosti razvio je Albert Bandura u okviru socijalno kognitivne teorije, a radi se o vjerovanju pojedinca u sposobnost da ostvari određeno postignuće (Bandura, 2006.). U posljednja dva desetljeća samoefikasnost zadobiva značajnu pozornost istraživača u socijalnom radu zbog svog potencijala u području mjerenja ishoda obrazovanja (Holden, Anastas i Metrey, 2002.; Green, 2003.; Rishel i Majewski, 2009.; Ahn i sur., 2012.) te pokazane pouzdanosti u predviđanju niza budućih ponašanja u izvedbi u različitim profesijama (Ewart, 1995.; Holden, 1991.; Holden i sur., 1990.; OXeary, 1985.; Strecher i sur., 1986.; Zimmerman, 1995., prema Holden, Meenagha i Rosenberg, 1999.; Holden, Anastas i Metrey, 2002.). 
Jedan od najznačajnijih autora u istraživačkoj praksi mjerenja profesionalnih kompetencija u socijalnom radu je Gary Holden koji je sa suradnicima razvio niz specijaliziranih skala (npr. "SWSE - Social Work Self- Efficacy Scale"). Upravo njihove, opetovano modificirane i validirane, skale najčešće su korištene generalno u istraživačkoj praksi mjerenja kompetencija u socijalnom radu. Skale pokazuju dobra psihometrijska svojstva (npr. "RSE" - Chronbach alfa koeficijent 0,94 na pretestu i postestu) (npr. Rishel i Majewski, 2009.; Ahn i sur., 2012.) te demonstriraju osjetljivost na promjenu tijekom vremena (Holden, Meenaghan i Rosenberg, 1999.; Holden i sur., 2008.). S obzirom na ovisnost kompetencija o specifičnostima nacionalnog konteksta, neki autori na temelju definiranih obrazovnih ishoda studija socijalnog rada u okviru kojeg djeluju te specifičnosti nacionalne prakse razvijaju vlastite skale vođeni onim već postojećim (Ricijaš, Huić i Branica, 2007.; Rishel i Majewski, 2009.; Rawlings, 2012.; Baartman i Ruijs, 2011.; Wang i Chui, 2016.; Tompsett i sur., 2017. itd.).

Temeljem pregleda dosadašnjih istraživanja zaključuje se kako se samoefikasnost procjenjuje primjenom različito stupnjevanih skala $(1-5,1-10$ ili 1-100 s jedinicama po 10). Prema Bandurinom vodiču (2006.), predloženo je korištenje 11-stupanjskih ljestvica od 0 do 100, s razmacima od 10 jedinica pri čemu 0 znači "ne mogu izvesti", 50 "umjereno sam uvjeren u mogućnost izvedbe" i 100 "vrlo sigurno mogu izvesti". Takve 11-stupanjske ljestvice koriste, primjerice, Holden i sur. (2002.) i Holden, Anastas i Metrey (2002.). Kao druga opcija predložen je oblik ljestvice u kojoj je zadržana ista struktura i deskriptori uz razliku korištenja jediničnih intervala u rasponu od 0 do 10. Slično predloženoj opciji, Rawlings (2012.) se koristi Likertovom skalom procjene na 10 stupnjeva (0 do 9 gdje 0 znači "uopće nemam pouzdanja" i 9 "imam potpuno povjerenje") pri tome ne objašnjavajući razloge korištenja upravo takve ljestvice.

Ljestvice od 5 stupnjeva, prema Banduri (2006.), treba izbjegavati jer su manje osjetljive i manje pouzdane. Međutim, iz pregleda dosadašnjih istraživanja čini se kako određeni broj autora ipak koriste upravo 5-stupanjske ljestvice (npr. Parker, 2006.; Baartman i Ruijs, 2011.; Wang i Chui, 2016.; Ricijaš, Huić i Branica, 2007.; Tompsett i sur., 2017.). Parker (2006.) navodi kako 5-stupanjsku ljestvicu odabire kako bi spriječio predugo razmišljanje o malim promjenama unatoč tome što 11-stupanjske sugeriraju veću osjetljivost. Tompsett i sur. (2017.) prilikom validacije njihovog mjernog instrumenta takvoj 5-stupanjskoj ljestvici dodaju i šesti stupanj odgovora (X) značenja "ne razumijem značenje ove vještine". Međutim, nedostaje osvrt autora na korisnost uvođenja takvog šestog stupnja odgovora. Takav podatak mogao bi biti koristan drugim istraživačima u planiranju vlastitog istraživanja, odnosno konstrukciji vlastitih mjernih instrumenata.

Nadalje, kao što je već ranije istaknuto, operacionalizacija skala uvelike ovisi o specifičnostima nacionalnog konteksta prakse socijalnog rada, ali i o kurikulumu 
studija socijalnog rada u okviru kojeg djeluju istraživači. Stoga se može tvrditi kako su razlike uočljive čak i unutar zasebnih nacionalnih konteksta, s time da se kao najčešće utvrđena područja profesionalnih kompetencija u istraživanjima uzimaju ranije objašnjena područja u ovom radu, koja se sastoje od metakompetencija i procesnih kompetencija. Različiti načini operacionalizacije područja i indikatora profesionalnih kompetencija socijalnih radnika posebno se ogledaju u broju čestica i subskala od kojih su konstruirani istraživački instrumenti.

Tako Holden, Anastas i Metrey (2002.), Holden, Anastas i Meenaghan (2005.) i Holden i sur. (2017.) u SAD-u razvijaju skale s manjim brojem čestica (npr. 52, 41, 31, 14), jednako kao i Rawlings (2012.) koji se koristi skalom od 37 čestica (Cronbach alfa: 0,98). U Kini Wang i Chui (2016.) su razvili skalu s ukupno 48 čestice (Chronbach alfa: 0,964), dok u Engleskoj Tompsett i sur. (2017.) razvijaju skalu s 29 čestica (Chronbach alfa: 0,89). Manje uobičajeno je da skale sadrže veći broj čestica kao što je slučaj s američkim skalama Rishela i Majewskog (2009.) koja sadrži 129 čestica u 17 subskala (Chronbach alfa na subskalama varira od 0,74 do 0,96) ili skala Macgowana i Wonga (2015.) sa 70 čestica vezanih za kompetencije socijalnih radnika u grupnom radu (Chronbach alfa: 0,97).

U Hrvatskoj su Ricijaš, Huić i Branica (2007.) razvili "Skalu percipirane kompetentnosti za budući psihosocijalni rad (SPKPR)" s 30 čestica (4 faktora: "neposredni rad u praksi", "grupni rad/ preventivni programi", "empatija i uspostavljanje odnosa", "primjena teorijskih znanja u praksi"). Ova skala primijenjena je u dva dosadašnja istraživanja na hrvatskim uzrocima (Chronbach alfa: 0,92) (Leutar i Žilić, 2014.). Dodatno, isti autori razvijaju i "Skalu usvojenosti ključnih kompetencija za socijalni rad" (Huić, Ricijaš i Branica, 2010.), a koja se sastoji od 10 kompetencija u području socijalnog rada ("uspostavljanje kvalitetnog odnosa s korisnicima", "pisanje stručnog nalaza i mišljenja", "evaluaciju uspješnosti tretman" itd.) (Cronbach alfa: 0,82) (Leutar i Žilić, 2014.). Ove skale prilagođene su primjeni na studenskim populacijama dok nedostaje skala koje bi svoju primjenu našle na populaciji stručnjaka socijalnih radnika.

Osim toga, neki autori se u svojim istraživanjima za mjerenje profesionalnih kompetencija koriste s nekoliko mjernih instrumenata. Primjerice, u Hrvatskoj Leutar i Žilić (2014.) koriste "Skalu percipirane kompetentnosti za budući psihosocijalni rad (SPKPR)" i "Skalu usvojenosti ključnih kompetencija za socijalni rad" (Huić i sur., 2010.), a Ricijaš, Huić i Branica (2007.) uz "Skalu percipirane kompetentnosti za budući psihosocijalni rad (SPKPR)" koriste kao kontrolnu varijablu i "Skalu percipirane nekompetenosti" (Bezinović, 1988.). Rawlings (2012.) kombinira korištenje metode intervjua sa standardiziranim klijentom te dvije skale za mjerenje samoefikasnosti u vještinama direktne prakse. Ukoliko se u istraživanjima koristi samo jedan mjerni instrument samoefikasnosti (npr. Ahn i sur., 2012.; Simmons i sur., 2017.), ista ne pružaju podatke 
o stvarnom stupnju kompetentnosti studenata. Također, istraživanja provođena na studentskoj populaciji, a koja su pratila procjene samoefikasnosti studenata tijekom obrazovnog procesa rijetko pridaju pozornost izolaciji utjecaja vanjskih elemenata, a koji su mogli imati utjecaja na procjenu samoefikasnosti. Primjerice, kolegija koji nisu vezani uz socijalni rad (koje su studenti pohađali), iskustva stečenog izvan studija (npr. Rawlings, 2012.), percepcije osobne (ne)kompetentnosti (Ricijaš, Huić i Branica, 2007.), prosječne ocjene na studiju i drugih. Osim toga, prema Ricijaš, Huić i Branica (2007.), istraživanja u području kompetencija trebala bi uključivati i objektivnije mjere, poput testova znanja i provjere usvojenih vještina, simulacije radnih situacija (npr. Rawlings, 2012.) te snalaženja u stvarnim radnim uvjetima. Na takve podatke mogli bi se u većoj mjeri osloniti prilikom evaluacije studijskog programa.

\section{REZULTATI ISTRAŽIVANJA MJERENJA PROFESIONALNIH KOMPETENCIJA}

U Hrvatskoj na znanstvenoj razini kompetencije u socijalnom radu jesu prepoznate kao važan konstrukt (primjerice, Ricijaš, Huić i Branica, 2006.; Huić, Ricijaš i Branica, 2010.; Matković i sur., 2015.; Leutar i Žilić, 2014.; Štambuk i Obrvan, 2017.). Međutim, ne postoji jasno definiran okvir profesionalnih kompetencija na nacionalnoj razini, niti razvijena praksa praćenja/ mjerenja razvoja kompetencija. U Hrvatskoj, jednako kao i u globalnoj istraživačkoj praksi, dominira mjerenje studentskih kompetencija povezano s obrazovnim ishodima, međutim nedostaju istraživanja na populacijama praktičara. Također, s obzirom na kontekstualnu ovisnost kompetencija, te uočene razlike u operacionalizaciji područja i indikatora kompetencija, otežana je usporedba rezultata istraživanja i replikacija u drugačijim nacionalnim pa čak i regionalnim kontekstima iste države.

U dosadašnjim istraživanjima u području mjerenja profesionalnih kompetencija dominantno se koristi kvantitativna metodologija primjenom metode ankete (najčešće direktno anketiranje ili e-mail ankete/ web ankete s, primjerice, izvanrednim studentima), a manje kvalitativne istraživačke metode. Kvalitativne metode obično se koristi prilikom stvaranja okvira kompetencija. Kada se koriste u mjerenju profesionalnih kompetencija, tada se najčešće koriste intervjui uz primjenu vinjeta (npr. Regehr i sur., 2012.) ili intervjui sa standardiziranim klijentom (npr. Rawlings, 2012.). Takva "upotreba" standardiziranih klijenata uobičajena je u medicini, no tek se počinje upotrebljavati u literaturi socijalnog rada (Badger i MacNeil, 2002.; Miller, 2004.). U ulozi standardiziranog klijenta uobičajeno se nalazi glumac obučen za predstavljanje vinjete koja opisuje situaciju u kojoj bi se sudionici mogli naći u praksi. Ukoliko su takvi intervjui snimani kamerom, isto nam omogućava izravnu procjenu vještina, istodobno izlažući sve sudionike istom problemu i stupnju poteškoće, omogućujući 
procjenu varijacija u vještinama (Rawlings, 2012.). Standardizirani klijent za ovo istraživanje razvijen je u skladu sa smjernicama predstavljenim u literaturi za povećanje pouzdanosti i valjanosti (Collins i Hardin, 1998.; van der Vleuten i Swansen, 1990.; Vu i Barrow, 1994., prema Rawlings, 2012.).

Rezultati se, kako je i prikazano u Tablici 1., najčešće interpretiraju u kontekstu viših i nižih procjena samoefikasnosti na dimenzijama profesionalnih kompetencija te promjena u samoprocjeni u određenoj vremenskoj dimenziji (npr. od početka semestra do kraja).

Tablica 1. Usporedba rezultata istraživanja - (samo)procjena kompetencija

\begin{tabular}{|c|c|}
\hline Više procjene & Niže procjene \\
\hline $\begin{array}{l}\text { - Sposobnosti suradnje i usvajanja novih znanja, pisanje } \\
\text { izvještaja, koordinacija i učinkovito djelovanje pod pri- } \\
\text { tiskom; primjena metoda u izravnom radu s korisnicima } \\
\text { (Matković i sur., 2015.). } \\
\text { - Kompetencije za pristupanje korisniku s empatijom i ra- } \\
\text { zumijevanjem te za rad u skladu s etičkim vrijednostima } \\
\text { (Leutar i Žilić, 2014.). } \\
\text { - Uspostavljanje kvalitetnog odnosa s korisnikom, prepo- } \\
\text { znavanje i opisivanje problema i rad u skladu s etičkim } \\
\text { kodeksom (Ricijaš, Huić i Branica, 2006.). } \\
\text { - Sposobnosti korištenja empatije, pružanja emocionalne } \\
\text { podrške korisnicima, isticanja uspjeha korisnika kako bi } \\
\text { povećali samopouzdanje i stvaranja odnosa povjerenja s } \\
\text { korisnicima (Holden, Anastas i Metrey, 2002.). } \\
\text { - Postupanje bez diskriminacije s obzirom na dob, boju } \\
\text { kože, invaliditet, kulturnu i etničku pripadnost, rasu, spol, } \\
\text { obiteljsku strukturu i drugo (Ahn i sur., 2012.). } \\
\text { - Primjenjivanje nediskriminacijske prakse, znanja i vještina } \\
\text { vezana uz korisnikov bračni status, spol iseksualnu orijen- } \\
\text { taciju (Holden, Anastas i Meenaghan, 2003., 2005.). } \\
\text { - Komunikacijske vještine, etička predanost, rješavanje pro- } \\
\text { blema i interpersonalni odnosi (Applewhite, Kao i Pritzker, } \\
\text { 2017.). } \\
\text { - Identifikacija kao profesionalni socijalni radnik, etika, kri- } \\
\text { tičko promišljanje i komuniciranje, uvažavanje različitosti } \\
\text { te uključivanja u političke prakse (Guo i sur., 2016.). } \\
\text { - Prilagođavanje vlastite komunikacije s različitim korisnici- } \\
\text { ma, sposobnosti djelovanja s različitostima, prepoznavanje } \\
\text { uloge supervizije i konzultacija u praksi (Rishel i Majewski, } \\
\text { 2009.). }\end{array}$ & $\begin{array}{l}\text { - Područje socijalne politike (Rishel i Majewski, 2009.; } \\
\text { Adams, 2004.; Anderson i Harris, 2005., prema Ahn i } \\
\text { sur., 2012.; Matković i sur., 2015.; Guo i sur., 2016.). } \\
\text { - Formuliranje, analiziranje i utjecaj na socijalne politike } \\
\text { te evaluiranje istraživačkih studija (Holden, Anastas i } \\
\text { Meenaghan, 2003.). } \\
\text { - Primjena međunarodnih standarda prakse (Matković } \\
\text { i sur., 2015.). } \\
\text { - Obavljanje posla pod pritiskom i uspješno pregovaranje } \\
\text { (Matković i sur., 2015.). } \\
\text { - Primjena znanstveno-istraživačkih metoda (Leutar i } \\
\text { Žilić, 2014.; Matković i sur., 2015.). } \\
\text { - Planiranje tretmana, pisanje stručnog mišljenja te rad } \\
\text { na promjeni korisnika (Leutar i Žilić, 2014.). } \\
\text { - Primjena znanja o multikulturalnim razlikama, upravlja- } \\
\text { nje radom drugih, prezentacija u javnosti i iskazivanje } \\
\text { profesionalnog autoriteta (Matković i sur., 2015.). } \\
\text { - Korištenje teorije u praksi (Parker, 2005.; Ahn i sur., } \\
\text { 2012.). } \\
\text { - Sposobnosti kritičke analize zakonodavstva, evaluacije } \\
\text { vlastite prakse korištenjem relevantnih istraživačkih } \\
\text { metoda, sudjelovanja u korištenju istraživačkih metoda } \\
\text { za adresiranje problema u praksi i organizacijskom } \\
\text { okruženju (Holden, Anastas i Metrey, 2002.). } \\
\text { - Kritičko mišljenje (logičko i znanstveno rezoniranje - } \\
\text { npr. dokazati tvrdnje na logičan, racionalan, sustavan } \\
\text { način temeljen na podacima) (Rishel i Majewski, 2009.). } \\
\text { - Posvećenost vrednovanju profesionalnog znanja i } \\
\text { diseminacija profesionalnog znanja (Rishel i Majewski, } \\
\text { 2009.). }\end{array}$ \\
\hline
\end{tabular}


Iz pregleda istraživanja u Tablici 1., koja su provedena najvećim dijelom na studentskoj populaciji (izuzetak su Applewhite, Kao i Pritzker, 2017.), vidljivo je kako su područja nižih procjena većinski područja metakompetencija, a procesne kompetencije češće zastupljene u području viših procjena uz dodatno značajniju zastupljenost dvaju područja metakompetencija: multikulturalnosti i zagovaranja ljudskih prava. Naime, neka istraživanja pokazuju kako su studenti najmanje uvjereni u svoje sposobnosti primjene vještina iz područja socijalne politike (Holden, Anastas i Metrey, 2002.; Holden, Anastas i Meenaghan, 2003.; Adams, 2004.; Anderson i Harris, 2005., prema Ahn i sur., 2012.; Matković i sur., 2015.; Guo i sur., 2016.), smatrajući ga zbunjujućim i nerelevantnim za izravnu praksu (Adams, 2004.; Anderson i Harris, 2005. prema Ahn i sur., 2012.). Potencijalno objašnjenje za takve rezultate nude Guo i sur. (2016.) tvrdeći da je moguće da studenti imaju snažnije preferencije prema praksi socijalnog rada na mikrorazinama ili imaju visoke standarde u procjenjivanju vlastite kompetencije u segmentu socijalnih politika.

U području znanstveno-istraživačkih metoda sudionici imaju slabija uvjerenja u vlastite sposobnosti, ali i niže procjene relevantnosti tih kompetencija za posao (Leutar i Žilić, 2014.; Matković i sur., 2015.). Takvi rezultati prvenstveno ukazuju na potrebu osvještavanja važnosti korištenja istraživanja u praksi jer mogu omogućiti da se znanstveno utemeljenom praksom unaprijede intervencije socijalnog rada. Nadalje, istraživanja pokazuju kako su studenti slabo uvjereni u vlastite sposobnosti korištenja teorijskih okvira u praksi (Ahn i sur., 2012.; Parker, 2005.; Holden, Anastas i Metrey, 2002.), posebice teorija o razvoju pojedinaca i ponašanja kroz životni vijek te o interakcijama na razinama pojedinaca i obitelji, grupa, organizacija i zajednice. Ovakvi rezultati mogu dovesti do zaključka kako se nedovoljno razvija kritičko mišljenje u praktičnoj i fakultetskoj nastavi (slično zaključuju npr. Rishel i Majewski, 2009.).

Kao što je već naglašeno, kvalitativna istraživanja usmjerena su na konceptualizaciju područja kompetencija. Tako su temeljem kvalitativnog pristupa s terenskim instruktorima Regehr i sur. (2012.) predložili kriterije za razlikovanje studenata koji mogu poslužiti kao primjer (eng. exemplary students), od prosječnih studenata. Visoka razina kompetentnosti prema terenskim instruktorima uključuje: snažnu konceptualnu i analitičku sposobnost (korištenje kritičkog mišljenja, različitih teorijskih perspektiva, otvoreno promišljanje i razmišljanje široko i iz perspektive socijalne pravde i osnaživanja); sposobnost stvaranja i održavanja poštujućih profesionalnih odnosa - s kolegama, timovima i sa širokim rasponom dionika u zajednici; kulturne kompetencije; sposobnost rada s marginaliziranim skupinama klijenata te sposobnost slušanja i razmatranja različitih mišljenja. Terenski instruktori prosječnim studentima pripisuju mnogo procesnih kompetencija: vještine pisanja, povezivanje teorije i prakse; sposobnost dovršavanja zadataka (projekta); vještine profesionalnog komuniciranja te 
planiranja i implementacije (osjetljivost na politike, pisanje izvještaja, prezentacijske vještine i dr.) (Regehr i sur., 2012.).

\section{PROFESIONALNE KOMPETENCIJE U SPECIFIČNIM PODRUČJIMA SOCIJALNOG RADA}

Budući da se socijalni radnici u svom profesionalnom djelovanju susreću s različitim skupinama korisnika, kojima je potrebno pristupati na maksimalno individualizirani način, za zaključiti je kako postoje različite profesionalne kompetencije koje trebaju posjedovati i s kojima korisnici osiguravaju zadovoljenje životnih potreba, realizaciju njihovih prava, poboljšavaju njihovu kvalitetu života i djeluju s ciljem kvalitetnije uključenosti u društvo. Shodno velikom broju različitih skupina korisnika, posljednjih desetljeća došlo je do razvoja specifičnih područja socijalnog rada. Samim time dolazi i do razvoja specifičnih i specijaliziranih profesionalnih kompetencija. $U$ suvremenoj stručnoj i znanstvenoj literaturi, specifičnim područjima socijalnog rada smatraju se određena profesionalna područja socijalnog rada, od kojih su neka još uvijek nedovoljno razvijena u hrvatskom kontekstu. Slijedi prikaz kako su u pojedinim područjima socijalnog rada specifično određene profesionalne kompetencije.

U socijalnom radu u zdravstvu u SAD-u profesionalne kompetencije su: teorijsko utemeljenje djelovanja, ovladavanje znanjima vezanim za metodologiju i procese analize, napredno profesionalno znanje, komunikacijske vještine, uzimanje anamnestičkih podataka/ vođenje dokumentacije, psihosocijalna procjena, kliničke intervencije, evaluacija rezultata tretmana, kliničko znanje politika i praksa, vrijednosti i etika, kulturne i jezične kompetencije, izgradnja odnosa međusobne suradnje, rukovodstvo, menadžment, unaprjeđenje, trening i razvoj, politika i zastupanje, te istraživanja i evaluacija (Association of State and Territorial Public Health Social Workers, 2005.; Ow Yong i sur., 2014.; National Association of Social Workers, 2016.).

U kliničkom socijalnom radu navode se sljedeće profesionalne kompetencije koje bi socijalni radnici trebali posjedovati i primjenjivati u svom radu: proširivati raznolikost svoje kliničke prakse, povećati vlastita znanja o etičkim i pravnim parametrima prakse, povećati praktične vještine, prepoznati korisnike koji su u riziku i adekvatno intervenirati u tom slučaju, povećati znanja o praktičnim metodama i teorijama, postići integritet svojih profesionalnih uvjerenja, diferencirati klinička opažanja od zaključivanja, postići sigurnosti u vlastite kliničke procjene, definirati profesionalni stav nasuprot realnosti prakse u kojoj socijalni radnik djeluju, razumjeti i prihvatiti ograničenja u praksi te razviti koncepte i plan za vlastiti profesionalni razvoj (American Board of Examiners in Clinical Social Work, 2002.). 
U socijalnom radu u području mentalnog zdravlja u SAD-u, Australiji i Španjolskoj kompetencije su: identifikacija s profesionalnim socijalnim radnikom i ponašanje u skladu s identifikacijom, primjena etičkih principa socijalnog rada u profesionalnom djelovanju, kulturne kompetencije, razvoj metoda procjena socijalnog rada, primjena kritičkog mišljenja kod informiranja i komuniciranja o profesionalnim prosuđivanjima, uspostavljanje odnosa poštovanja i empatičkog odnosa između korisnika i socijalnog radnika, motivacijsko intervjuiranje, procjena funkcionalnosti korisnika, uključivanje, procjena, intervencije, evaluacija, razumijevanje obiteljskog sustava, primjena znanja o ljuskom ponašanju i socijalnoj okolini. Nadalje, to su i razvoj i primjena različitih psihosocijalnih intervencija, vođenje slučaja, zastupanje s i u ime korisnika, razvoj procjene potreba i resursa zajednice, skrb temeljena na timskom radu, tretman rješavanja problema, kognitivno-bihevioralna terapija, opuštajuća terapija, pružanje skrbi osobama s kroničnim bolestima, razumijevanje farmakološke terapije, procjena intervencija zbog zlouporabe sredstava ovisnosti, psihoedukacija, uključivanje u promociju mentalnog zdravlja, unaprjeđenje poštovanja ljudskih prava te socijalne i ekonomske pravde, razvoj mreža, uključivanje u aktivnosti socijalne akcije, uključivanje u političko djelovanje kako bi se unaprijedila ekonomska i socijalna dobrobit i osigurale djelujuće usluge socijalnog rada, odgovaranje na kontekst koji oblikuje praksu, uključivanje raznolikosti i različitosti u praktično djelovanje te uključivanje u informirana istraživanja i praksu (Australian Association of Social Workers, 2008.; Horevitz i Manoleas, 2013.; Lusk i sur., 2014.; Council on Social Work Education, 2019.).

Profesionalne kompetencije vezane uz socijalni rad u gerijatriji su pristupačnost, zastupanje, prepoznavanje ageizma, procjena, autonomnost, vođenje slučaja, komunikacija, kulturna kompetentnost, emocionalna podrška, interdisciplinarna suradnja, umrežavanje, planiranje, pronalaženje resursa, svijest o sebi, te znanje o potrebama (invaliditetu) (Naito-Chan, Damron-Rodriguez, i Simmons, 2005.), dok su u području socijalnog rada s osobama s invaliditetom razvoj kapaciteta i razumijevanja potreba osoba s invaliditetom, edukacija, trening i profesionalni standardi (National Disability Authority, 2016.).

U socijalnom radu u palijativnoj skrbi u Europi, Kanadi i SAD-u profesionalne kompetencije su: pokazati znanje o hospiciju i palijativnoj skrbi, primjena profesionalnosti i etike, svijest o sebi i uspostavljanje profesionalnih granica, mogućnost uspostavljanja i održavanja odnosa, procjena, razumijevanje korisnikovog ponašanja, vještine savjetovanja, podržavanje korisnika u raspravi o njegovom medicinskom stanju i ograničenjima u životu, zastupanje, planiranje tretmana, intervencija i skrbi, donošenje odluka, pronalazak najboljeg rješenja vezanog za pružanje skrbi korisniku, interdisciplinarni timski rad, razmjena informacija, evaluacija, razvoj kapaciteta zajednice, kontinuirano razvijanje osobnih vještina i kompetencija, obrazovanje i 
istraživanje, supervizija, upravljanje, trening i samoreflektirajuća praksa (Gwyther i sur., 2005.; Bosma i sur., 2008., 2010.; Hughes, Firth i Oliviere, 2015.; National Hospice and Paliative Care Organization, 2019.).

Specifične profesionalne kompetencije u socijalnom radu s osobama s problemima ovisnosti su etika i profesionalizam, kulturna raznolikost, mentalno zdravlje, farmakologija, prevencija i promocija zdravlja, utvrđivanje i procjena, planiranje tretmana, timski rad, vođenje slučaja, savjetovanje, rješavanje sukoba, krizne intervencije, podrška obitelji i socijalna podrška, upravljanje grupom, razumijevanje zloupotrebe sredstava i ovisnosti o nečemu, razvoj zajednice, provedba i evaluacija programa (Graves i sur., 2009.).

Socijalni radnici koji rade s djecom u ruralnim sredinama trebali bi imati sljedeće profesionalne kompetencije: znanja o siromaštvu, resursima u zajednici, traumama, kulturnu kompetentnost, primjena ekološko-sistemske teorije, autonomnost i potreba za podrškom socijalnih radnika, uzajamni odnosi, upravljanje, suradnja znanstvene i lokalne zajednice (Riebschleger i sur., 2015.).

U svim područjima socijalnog rada za koji je razvijen specifični okvir kompetencija može se uočiti kako ga uglavnom čine prethodno određene generičke kompetencije uz dopunu nekih specifičnih vještina, metoda i znanja. To ukazuje kako je u budućnosti vrijedno uložiti napore u stvaranje nacionalnog okvira generičkih profesionalnih kompetencija u socijalnom radu koji bi imao široku mogućnost primjene i u specifičnim područjima socijalnog rada.

\section{ZNAČAJ I ULOGA PROFESIONALNIH KOMPETENCIJA U HRVATSKOM KONTEKSTU}

Profesionalne kompetencije socijalnih radnika od izuzetne su važnosti u hrvatskom nacionalnom kontekstu. Naime, socijalni rad kao regulirana djelatnost u Hrvatskoj odlikuje se kako multidimenzionalnošću, tako i zahtjevnošću posla. Stručnjaci praktičari mnogo puta se susreću sa situacijama u kojima se tijekom timskog rada ne poznaju jasna zaduženja različitih stručnjaka koji zajednički djeluju u stručnom timu. Definiranje profesionalnih kompetencija iz nacionalnog rakursa doprinijet će i jačanju struke socijalnog rada, kao i sve većoj profesionalizaciji iste. Zakon o djelatnosti socijalnog rada (2019.) navodi kako testiranju kompetencija pristupa socijalni radnik po uspješnom završetku vježbeničkog staža kroz pristupanje ispitu stručnih znanja i kompetencija (stručni ispit ili državni stručni ispit s posebnim dijelom iz upravnog područja socijalne skrbi ili ispit stručnih znanja i kompetencija pri Hrvatskoj komori socijalnih radnika). Zakonom se izričito naglašava kako ovlašteni socijalni radnik 
ima pravo i obvezu stručnog usavršavanja zbog održavanja i unaprjeđenja kvalitete provođenja stručnih postupaka i mjera, ali i pravo na stjecanje specijaliziranih stručnih kompetencija potrebnih za pojedino područje socijalnog rada. Etički kodeks socijalnih radnica i socijalnih radnika u djelatnosti socijalnog rada (Hrvatska komora socijalnih radnika, 2015.) isto tako kao vrijednost socijalnog rada navodi razvoj profesionalnih kompetencija, definirajući da je dužnost socijalnih radnika kontinuirano razvijati vlastitu kompetenciju kroz osobni rast i razvoj, profesionalnu izobrazbu i cjeloživotno obrazovanje, ali i da kontinuirani profesionalni razvoj kroz stjecanje i poboljšanje profesionalnih kompetencija ima cilj pružanje najbolje usluge korisnicima.

Osam područja profesionalnih kompetencija može poslužiti kao referenti okvir u hrvatskom nacionalnom kontekstu, na način da su ona prema promišljanjima autora ovog rada povezana s aktualnom praksom socijalnog rada na sljedeće načine:

1. Navedeno ukazuje na važnost cjeloživotnog obrazovanja kroz stjecanje i pospješivanje kompetencija temeljenih na suvremenim znanstvenim i stručnim spoznajama.

2. Rad socijalnih radnika u Hrvatskoj uvelike ovisi o procesnim kompetencijama u socijalnom radu, budući da ih većina na svojim poslovima koristi metode i alate socijalnog rada u neposrednom radu s korisnicima. Upravo je potrebno sustavno raditi na razvoju ovih kompetencija kroz ciljane edukacije i razvoj nacionalnih alata socijalnog rada, poput protokola u radu s pripadnicima određenih manjinskih skupina, ali i skupinama u nepovoljnom socioekonomskom položaju u hrvatskom društvu (npr. dugotrajno nezaposlene osobe s invaliditetom, jednoroditeljske obitelji, žrtve nasilja u obitelji i slično). Navedeno se treba temeljiti na razvoju sustava evaluacije usluga koje socijalni rad pruža korisnicima, ali i razvoju protokola za procjenu rizika s kojima se korisnici susreću te protokola vezanih za rad s nedobrovoljnim korisnicima. Zakonodavni okvir je u nekim slučajevima prepreka razvoju ovog područja kompetencija jer je u nekim slučajevima u suprotnosti s vrijednostima socijalnog rada (ostaje upitno koliko određena prava i usluge pridonose poštovanju ljudskih prava određenih skupina korisnika i njihovom poboljšanju kvalitete života, uključenosti u zajednicu i antidiskriminativnim politikama).

3. Profesionalno ponašanje i profesionalni identitet mogu ostati kao kompetencija nedovoljno prepoznati, budući da u određenim područjima socijalnog rada i dalje ne postoji jasna distinkcija podjele odgovornosti i zadataka između pomažućih struka koje čine tim stručnjaka.

4. Ostaje upitno koliku mogućnost imaju socijalni radnici u Hrvatskoj da osvješćuju poziciju moći, budući da određena postupanja definirana pravnim izvorima bivaju obilježena nesuradničkim odnosom. 
5. Kompetencija profesionalne etike nužna je za rad svakog socijalnog radnika, s time da se u nacionalnom kontekstu treba raditi na osvještavanju socijalnih radnika da je sudjelovanje korisnika u donošenju odluka jedno od osnovnih načela socijalnog rada, a povezano je sa zauzimanjem pozicije moći.

6. Načelo multikulturalnosti i inkluzivne prakse u hrvatskom kontekstu trebalo bi rezultirati sviješću socijalnih radnika da su upravo multikulturalnost i uključivanje u život zajednice na najviše mogući ravnopravni način rješenje za poboljšanje kvalitete života određenih skupina korisnika sustava socijalne skrbi.

7. Kritički strukturalni pristup trebao bi biti jedan od temelja socijalnog rada, budući da su socijalni radnici u svom svakodnevnom radu svjesni izvora društvenih nejednakosti, osobito ukoliko su oni propisani pravnim izvorima koji definiraju rad socijalnih radnika u Hrvatskoj.

8. Integracija teorije u praksi i kritičko mišljenje kao kompetencija u hrvatskom kontekstu trebala bi predstavljati temelj za senzibilizaciju socijalnih radnika o važnosti cjeloživotnog obrazovanja, uz naglasak i osvješćivanje stručnjaka zaposlenih u praksi da je svako praktično i stručno djelovanje utemeljeno na teorijskoj podlozi.

9. Međusektorska suradnja i makropristup kao kompetencija u Hrvatskoj trebali bi rezultirati mogućnošću da socijalni radnici definiraju svoju jasnu ulogu u vodstvu, ali i unutar stručnih timova, što je povezano i s kompetencijom vodstvo i funkcioniranje u organizaciji.

Temeljem svega navedenog, razvoj nacionalnih profesionalnih kompetencija od izuzetne je važnosti za socijalni rad u Hrvatskoj, osobito u smislu razvoja identiteta struke.

\section{ZAKLJUČAK}

Cilj ovog rada bio je prikazati suvremeno shvaćanje profesionalnih kompetencija u socijalnom radu, dosadašnju istraživačku praksu te koristi pristupa utemeljenog na kompetencijama za profesiju socijalnog rada. Pregledom spoznaja može se zaključiti kako kompetencije treba shvaćati multidimenzionalno, više od uspješnosti izvršavanja radnih zadataka, a itekako više od raspolaganja znanjima i vještinama. Kompetentan socijalni radnik stalno razvija profesionalni integritet i profesionalni identitet, nastojeći ostvariti sklad osobnog i profesionalnog kroz sustav profesionalnih vrijednosti. Bitno je uložiti napore kako bi se izgradio nacionalni okvir općih profesionalnih kompetencija socijalnih radnika. Takav okvir u budućnosti daje podlogu za: 
a) jasno artikuliranje uloge socijalnog rada u društvu i pridonosi jačanju profesionalnog identiteta

b) služi kao podloga za razvoj sustava profesionalnog usavršavanja i karijernog razvoja socijalnih radnika

c) omogućava lakše usklađivanje obrazovnih programa s praksom socijalnog rada

d) daje profesionalni legitimitet stručnjacima da se njihova profesionalna uloga vidi i šire od zadataka propisanih zakonskim okvirima

e) otvara nova područja istraživanja u socijalnom radu u Hrvatskoj

f) pruža pogodnu osnovu za razvoj specifičnih kompetencija u područjima socijalnog rada.

Kako bi se ostvarile prethodno naznačene dobiti okvira profesionalnih kompetencija, od izuzetne je važnosti da u njegovoj izgradnji i daljnjem razvoju partnerski sudjeluje akademska zajednica, resorna ministarstava, praktičari i strukovne organizacije.

\section{LITERATURA}

1. Ahn, B., Boykin, L., Hebert, C. \& Kulkin, H. (2012). Exploring baccalaureate social work students' self-efficacy: Did it change over time?. Journal of Teaching in Social Work, 32 (5), 487-501. https://doi.org/10.1606\%2F1044-3894.239.

2. American Board of Examiners in Clinical Social Work (2002). Professional development and practice competencies in clinical social work. Marblehead: ABECSW.

3. Anderson-Levitt, K., Bonnéry, S. \& Fichtner, S. (2017). Introduction to the dossier. "Competence-based" approaches as "traveling" reforms: Ideas, trajectories and practices in implementation, Cahiers de la recherche sur l'éducation et les savoirs, 16. Preuzeto s: http://journals.openedition.org/ cres/3009 (29.4.2019.).

4. Applewhite, S. R., Kao, D. \& Pritzker, S. (2017). Educator and practitioner views of professional competencies for macro social work practice. International Social Work, 61 (6), 1-18. https://doi.org/10.1177\%2F0020872817702705.

5. Association of State and Territorial Public Health Social Workers (2005). Public health social work standards and competencies. Beverly Hills: ASTPHSW

6. Australian Association of Social Workers (2008). Practice standards for mental health social workers. Kingston: Australian Association of Social Workers. 
7. Australian Association of Social Workers (2013). Practice standards. Preuzeto s: https://www.aasw.asn.au/practitioner-resources/practice-standards (18.4.2018.).

8. Baartman, L. \& Ruijs, L. (2011). Comparing students' perceived and actual competence in higher vocational education. Assessment \& Evaluation in Higher Education, 36 (4), 385-398. https://doi.org/10.1080/02602938.20 11.553274.

9. Badger, L. \& MacNeil, G. (2002). Standardized clients in the classroom: A novel instructional technique for social work educators. Research on Social Work Practice, 12, 364-374. https://doi.org/10.1177\%2F1049731502012003002.

10. Bandura, A. (2006) Guide for constructing self-efficacy scales. In: Pajares, F. \& Urdan, T. S. (eds.), Self-efficacy beliefs of adolescents. Greenwich: Age Information Publishing, 307-337.

11. Bezinović, P. (1988). Samopercepcija osobne kompetentnosti kao dimenzija vrednovanja vlastitog ja. Doktorska disertacija. Zagreb: Filozofski fakultet, Odsjek za psihologiju.

12. British Association of Social Workers (2013). The Professional Capabilities Framework. Preuzeto s: https://www.basw.co.uk/pcf/PCF10EntryLevelCapabilities.pdf (18.4.2018.).

13. Bogo, M. (2010). Achieveing competence in social work through field education. Toronto: University of Toronto Press.

14. Bosma, H., Johnston, M., Cadell, S., Wainwright, W., Abernathy, N., Feron, A., Kelley, L. M. \& Nelson, F. (2008). Canadian social work competencies for hospice palliative care: A framework to guide education and practice at the generalist and specialist levels 2008. Preuzeto s: http://acsp.net/ media/7868/Social_Work_Competencies_July_2009.pdf (16.4.2019.).

15. Bosma, H., Johnston, M., Cadell, S., Wainwright, W., Abernethy, N., Feron, A. \& Nelson, F. (2010). Creating social work competencies for practice in hospice palliative care. Palliative Medicine, 24 (1), 79-87. https://doi. org/10.1177/0269216309346596.

16. Bracy, W. (2018). Building a competency-based curriculum in social work education. Journal of Teaching in Social Work, 38 (1), 1-17. https://doi.or g/10.1080/08841233.2017.1400496.

17. Canadian Association for Social Work Education (2014). Standards for accreditation. Preuzeto s: https://caswe-acfts.ca/wp-content/uploads/2013/03/CASWE-ACFTS.Standards-11-2014-1.pdf (18.4.2018.).

18. Council on Social Work Education (2019). Advanced social work practice competencies in mental health recovery. Preuzeto s: https://www.cswe. 
org/getattachment/Centers-Initiatives/Institutional-Research/Recovery-to-Practice Initiative/AdvancedSocialWorkPracticeCompetenciesinMentalHealthRecovery.pdf.aspx (23.4.2019.).

19. Council on Social Work Education. (2012). Social work field education core competencies and practice behaviors, (Sowk 688). Preuzeto s: http:// www.ssw.chhs.colostate.edu/field/files/Social Work Core Competencies Practice Behaviors.pdf (18.4.2018.).

20. Council on Social Work Education (2015). Educational policy and accreditation standards for baccalaureate and master's social work programs, 1-20. Preuzeto s: http://www.cswe.org/File.aspx?id=81660 (18.4.2018.).

21. Cournoyer, B. R. (2011). The social work skills workbook. Belmont: Brooks/ Cole, Cengage Learning.

22. Dominelli, L. (1996). Deprofessionalizing social work : Competencies and postmodernism. British Journal of Social Work, 26 (2), 153-175. https:// doi.org/10.1093/oxfordjournals.bjsw.a011077.

23. Drisko, J. W. (2014). Competencies and their assessment. Journal of Social Work Education, 50 (3), 414-426. https://doi.org/10.1080/10437797.2014 .917927.

24. Graves, G., Csiernik, R., Foy, J. \& Cesar, J. (2009). An examination of Canadian social work program curriculum and the addiction core competencies. Journal of Social Work Practice in the Addictions, 9 (4), 400-413.

25. Green, D. M. (2003). Self-efficacy: A communication model for the development of selfefficacy in the classroom. Journal of Teaching in Social Work, 23 (3/4), 107-116. https://doi.org/10.1300/J067v23n03_09.

26. Guo, Y. (2016). Competency-based education: Evidence from social work postgraduates from five universities in china. Asian Social Work and Policy Review, 10 (3), 280-294. https://doi.org/10.1111/aswp.12096.

27. Gwyther, L. P., Altilio, T., Blacker, S., Christ, G., Csikai, E. L., Hooyman, N., Kramer, B., Linton, J. M., Raymer, M. \& Howe, J. (2005). Social work competencies in palliative and end-of-life care. Journal of Social Work in End-of-Life \& Palliative Care, 1 (1), 87-120.

28. Holden, G., Meenaghan, T. \& Rosenberg, G. (1999). Reaerch self-efficacy: A new possibility for educational outcomes assessment. Journal of Social Work Education, 3, 463-467. https://doi.org/10.1080/10437797.1999.107 78982.

29. Holden, G., Anastas, J. \& Metrey, G. (2002). Outcomes of social work education: The case for social work self-efficacy. Journal of Social Work Education, 38 (1), 115-134. 
30. Holden, G., Anastas, J. \& Meenaghan, T. (2003). Determining attainment of the epas foundation program objectives: Evidence for the use of self-efficacy as an outcome. Journal of Social Work Education, 39 (3), 425-440. https://doi.org/10.1080/10437797.2003.10779147.

31. Holden, G., Anastas, J. \& Meenaghan, T. (2005). EPAS objectives and foundation practice self-efficacy: A replication. Journal of Social Work Education, 41 (3), 559-570. https://doi.org/10.5175/JSWE.2005.200404118

32. Holden, G., Barker, K., Rosenberg, G. \& Onghena, P. (2008.). The evaluation self-efficacy scale for assessing progress toward cswe accreditation-related objectives: A replication. Research on Social Work Practice, 18 (1), 42-46. https://doi.org/10.1177\%2F1049731507303954.

33. Holden, G., Barker, K., Kuppens, S. \& Rosenberg, G. (2017). Self-efficacy regarding social work competencies. Research on Social Work Practice, 27 (5), 594-606. https://doi.org/10.1177/1049731515586466.

34. Horevitz, E. \& Manoleas, P. (2013). Professional competencies and training needs of professional social workers in integrated behavioral health in primary care. Social Work in Health Care, 52 (8), 752-787. https://doi.org /10.1080/00981389.2013.791362.

35. Hrvatska komora socijalnih radnika (2015). Etički kodeks socijalnih radnica i socijalnih radnika u djelatnosti socijalnog rada. Zagreb: HKSR.

36. Hughes, S., Firth, P. \& Oliviere, D. (2015). Core competencies for palliative care social work in Europe: an EAPC White Paper-part 2. European Journal of Palliative Care, 22 (1), 38-44.

37. Huić, A., Ricijaš, N. \& Branica, V. (2010). Kako definirati i mjeriti kompetencije studenata - validacija skale percipirane kompetentnosti za psihosocijalni rad. Ljetopis socijalnog rada, 7 (2), 195-221.

38. King, M. E. (2003). Creation and validation of the social work student seIf-appraisal inventory. Doctoral thesis. Georgia: University of Georgia in Partial.

39. Leutar, Z. \& Žilić, M. (2014). Zadovoljstvo studijem i samoprocjena kompetentnosti u struci studenata socijalnog rada u Mostaru i Zagrebu. Socijalne teme: časopis za pitanja socijalnog rada i srodnih znanosti, 1 (1), 9-38.

40. Lusk, M., Baray, S. C., Palomo, J. \& Palacios, N. (2014). Teaching clinical social work in Spanish: Cultural competency in mental health. Journal of Teaching in Social Work, 34 (4), 443-453. https://doi.org/10.1080/08841 233.2014.932321.

41. Macgowan, M. J. \& Wong, S.E. (2017). Improving student confidence in using group work standards: A controlled replication. Research on Social Work Practice, 27 (4), 434-440. https://doi.org/10.1177\%2F1049731515587557. 
42. Matković, T., Ogresta, J., Zrinščak, S., Rimac, I. \& Grubišić, K. (2015). Zapošljivost i razvoj karijere osoba koje su diplomirale na Studijskom centru socijalnog rada Pravnog fakulteta Sveučilišta u Zagrebu između 2004. i 2010. godine. Zagreb: Pravni fakultet Sveučilišta u Zagrebu.

43. Miller, M. (2004). Implementing standardized client education in a combined BSW and MSW program. Journal of Social Work Education, 40, 87-102. https://doi.org/10.1080/10437797.2004.10778481.

44. Naito-Chan, E., Damron-Rodriguez, J. \& Simmons, W. J. (2005). Identifying competencies for geriatric social work practice. Journal of Gerontological Social Work, 43 (4), 59-78.

45. National Association of Social Workers (2016). ASW Standards for social work practice in health care settings. NASW: Washington, DC.

46. National Disability Authority (2016). National Guidelines on accessible health and social care services. NDA: Dublin.

47. National Hospice and Palliative Care Organization (2019). Social work competencies. Preuzeto s: https://www.nhpco.org/social-work-competencies (24.4.2019.).

48. Štambuk, A. \& Obrvan, T. (2017). Uloga, standardi i kompetencije socijalnih radnika u palijativnoj skrbi. Ljetopis socijalnog rada, 24 (1), 119-146. https://doi.org/10.3935/ljsr.v24i1.142.

49. Ow Yong, L. M., Lim, E. L. P., Khoo, O. R. L. \& Goh, S. C. (2014). Implementing competency-based medical social work education and training in an academic medicine center in Singapore. Human Service Organizations: Management, Leadership \& Governance, 38 (5), 459-470.

50. Parker, J. (2005). Developing perceptions of competence during practice learning. British Journal of Social Work, 36 (6), 1017-1036. https://doi. org/10.1093/bjsw/bch347.

51. Pedrazza, M., Trifiletti, E., Berlanda, S. \& Bernardo, G. (2013). Self-efficacy in social work: Development and initial validation of the self-efficacy scale for social workers. Social Sciences, 2 (3), 191-207. https://doi.org/10.3390/ socsci2030191.

52. Rawlings, M. A. (2012). Assessing bsw student direct practice skill using standardized clients and self-efficacy theory. Journal of Social Work Education, 48 (3), 553-576. http://dx.doi.org/10.5175/JSWE.2012.201000070.

53. Regehr, C., Bogo, M., Donovan, C., Lim, A. \& Anstice, S. (2012). Identifying student competencies in macro practice: Articulating the practice wisdom of field instructors. Journal of Social Work Education, 48 (2), 307-319. https://www.tandfonline.com/action/showCitFormats?doi=10.5175/ JSWE.2012.201000114. 
54. Ricijaš, N., Huić, A. \& Branica, V. (2006). Zadovoljstvo studijem i samoprocjena kompetentnosti studenata nekih pomagačkih profesija. Hrvatska revija za rehabilitacijska istraživanja, 42 (2), 51-68.

55. Riebschleger, J., Norris, D., Pierce, B., Pond, D. L. \& Cummings, C. (2015). Preparing social work students for rural child welfare practice: Emerging curriculum competencies. Journal of Social Work Education, 51 (2), S209-S224. https://doi.org/10.1080/10437797.2015.1072422.

56. Rishel, C. W. \& Majewski, V. (2009). Student gains in self-efficacy in an advanced MSW curriculum: A customized model for outcomes assessment. Journal of Social Work Education, 45 (3), 365-383. https://doi.org/10.5175/ JSWE.2009.200800101.

57. Tompsett, H., Henderson, K., Byrne, J. M., Mew, E. G. \& Tompsett, C. (2017). Self-efficacy and outcomes: Validating a measure comparing social work students' perceived and assessed ability in core pre-placement skills. British Journal of Social Work, 47 (8), 2384-2405. https://doi.org/10.1093/ bjsw/bcx001.

58. UNESCO (2019). Competency-based approaches. Geneve: International Bureau of Education.

59. Vijeće Europske unije (2017). Preporuka vijeća od 22. svibnja 2017.0 Europskome kvalifikacijskom okviru za cjeloživotno učenje i o stavljanju izvan snage Preporuke Europskog parlamenta i Vijeća od 23. travnja 2008. o uspostavi Europskoga kvalifikacijskog okvira za cjeloživotno učenje. Službeni list Europske unije, 2017/C 189/03.

60. Wang, Y. \& Chui, E. (2017). Development and validation of the perceived social work competence scale in China. Research on Social Work Practice, 27 (1), 91-102. https://doi.org/10.1177/1049731516631119.

61. Webb, S. A. (2016). Professional identity and social work. In: Dent, M., Bourgeault, I. L., Denis, J.-L. \& Kuhlmann, E. (eds.), The routledge companion to the professions and professionalism. London: Routledge, 837-852.

62. Williams, N. R., King, M. \& Koob, J. J. (2002). Social work students go to camp: The effects of service learning on perceived self-efficacy. Journal of Teaching in Social Work, 22, 55-70. https://doi.org/10.1300/ J067v22n03_05.

63. Zakon o djelatnosti socijalnog rada (2019). Narodne novine, 16/2019. 
Marko Buljevac

Ana Opačić

University of Zagreb

Faculty of Law

Department of Social Work

Martina Podobnik

Croatian chamber of social workers

\section{PROFESSIONAL COMPETENCES OF SOCIAL WORKERS: THE BASIS OF A HELPING PROFESSION'S IDENTITY}

\section{ABSTRACT}

This paper provides an overview of current understandings of competences in social work, which is shown by the research on assessing competences, and it explains the significance of the development of competence framework for social work in Croatia. Professional competences are understood as a result of the triangle of knowledge, skills and values, which emphasises the efficiency of work, but also the personal dimensions of a professional. Eight areas of generic competences for social work have been systematized, and these are procedural competences (for direct work with clients) and seven meta-competences: professional behaviour and professional identity, professional ethics, multiculturality and inclusive practice, critical structural approach, integration of theory in practice and critical thinking, intersectoral cooperation and macro approach and leadership and functioning in n organisation. In the analysed research practice, competences are usually assessed through self-evaluation and assessment of self-efficiency, and the assessment based on observation are less represented. Regardless of the assessment method, it is suggested that the competence framework and measuring instruments should be developed in accordance with the specific characteristics of the national context. The paper presents specific competence frameworks in individual areas of social work, but due to a marked correspondence with the generic framework, a conclusion is reached that the generic framework can be effectively upgraded for the application in the specific area of social work. The national framework of professional competences of social workers developed through the cooperation of the academic community, practitioners and professional organisations could contribute to the professional identity of social workers, improve their professional and career development, open new areas of research and serve as a basis for the development of specific competences in social work areas.

Key words: professional competences, professional identity, lifelong learning, social work. 